\title{
The Sustainable Developments Goals and Buddha's Teachings
}

Sabita Dhakhwa*

\begin{abstract}
The Sustainable Development Goals (SDGs), also known as the Global Goals, were adopted by all United Nations Member States in 2015 as a universal call to action to end poverty, protect the planet and ensure that all people enjoy peace and prosperity by 2030. The Buddha delivered several Dhamma discourses to diverse people in the various places for forty-five years; from the time he attained enlightenment until he entered into Mahaparinibbāna. These Dhamma discourses are related to non-violence, equality and peace. The elimination of all forms of gender based violence and promotion of equality are very much related with change of attitude and positive mind development. Moral conducts (Sila), Right speech, Right livelihood, Right understanding, practicing of loving kindness (Mettā, Saraniya Dhammas, etc are some of the Buddha's teachings which can contribute to attitude change and positive mind development. The teachings of the Buddha are in harmony with the spirit of Gender equality goal of SDGs. Therefore, the article intends to throw light on the following aspects: What are the Buddha's teaching for Gender equality? and how Buddha's teachings can contribute to eliminate gender based violence and promote Gender equality which is one of the goal of SDGs.
\end{abstract}

Key words: Sustainable Development Goals, Gender based Violence, Empowerment, Gender Equality, Buddha's Teachings.

\section{Objectives}

The objective of the article is to analyze the Buddha's Teachings for elimination of Gender based violence and promotion of Gender Equality, the fifth goal of Sustainable Development Goals.

\section{Methodology}

Primary sources of this paper are based on 'Pāli Tripitaka' and 'Pāli Literature'. Similarly, necessary data or information have been obtained from secondary sources: several published books, articles written by the scholars and various websites.

\footnotetext{
* Joint Coordinator, Teachers Training Committee Nepal Boudha Pariyatti Education
} 


\section{Background}

Sustainable Development Goals (SDGs) or Global Goals are a collection of 17 interlinked goals designed to be a "blueprint to achieve a better and more sustainable future for all". SDGs are a bold, universal agreement to end poverty in all its dimensions and craft an equal, just and secure world - for people, planet and prosperity by 2030. There are 17 SDGs which are focusing to transform our world: the 2030 Agenda for Sustainable Development, which was adopted by 193 Member States at the historic UN General Assembly Summit in September 2015. Out of 17 SDGs, Goal 5 is about Gender equality: Achieve Gender equality and empower all women and girl. The targets under goal no. 5 are to end all forms of discrimination against all women and girls everywhere, to eliminate all forms of violence against all women and girls in the public and private spheres, including trafficking and sexual and other types of exploitation, etc. ${ }^{1}$ The teachings of Buddha are seen identical with several markers of SDGs. In this context, Buddha's teachings can contribute to achieve sustainable development goals and eventually the Gender equality.

'The Convention on the Elimination of all Forms of Discrimination Against Women' (CEDAW) defines discrimination against women as "...any distinction, exclusion or restriction made on the basis of sex which has the effect or purpose of impairing or nullifying the recognition, enjoyment or exercise by women, irrespective of their marital status, on a basis of equality of men and women, of human rights and fundamental freedoms in the political, economic, social, cultural, civil or any other field."

Gender based violence is a global problem affecting millions of women and girls of all cultures, religions, socio-economic strata, educational levels and other diversity. It is one of the most notable human rights violations within all societies. Gender based violence is violence directed against a person because of their gender. Both women and men experience gender-based violence but the majority of victims are women and girls. Thus, gender-based violence and violence against women are terms that are often used interchangeably as it has been widely acknowledged that most gender-based violence is inflicted on women and girls, by men. ${ }^{3}$ The Buddha's Teachings can contribute to eliminate gender based violence and promote gender equality.

1 United Nations CounTrans.y Team in Nepal, UNDP. Sustainable Development Goals. Kathmandu:

United nations CounTrans.y Team in Nepal. 2016. pp. 13-15.

2 MinisTrans.y of Women, Children and Social Welfare, Nepal. The Convention on the Elimination of all Forms of Discrimination Against Women (CEDAW). Kathmandu: MinisTrans.y of Women, Children and Social Welfare. 2006. p. 2.

3 European Institute for Gender Equality. 'Gender-based Violence'. Google. 2019. Access on Nov. 5, 2019. 


\section{Different forms of Violence and the Causes of Violence}

There are different forms of violence exist in the world. These violence can be broadly classified into different categories ${ }^{4}$ : Domestic violence, Economic violence, Socio-cultural violence, Sexual abuse, Political and collective violence. In Nepal there are various forms of violence perpetuating as; Human trafficking, Domestic violence, Rape, Sexual harassment, Sex-selective abortions, Child and forced marriage, Accusations of witchcraft, Acid attack, Unsocial to Women of the 'Dalit' group so called untouchable, Violence against sexual minorities, Violence related to dowry, Harmful traditional practices such as chhaupadi and deuki and etc. ${ }^{5}$

The development practitioner put the concept that the root cause of violence is the unequal power relations between females and males, in most societies, which makes violence a critical gender issue. ${ }^{6}$ Buddhism not only explains the external conflicts and violence but also more on inner aspects. The root cause behind the violence is polluted mind filled with greed, hatred and delusion. The Buddha had shown the ways how these defilements can be eradicated.

\section{Buddha's Teachings to Eliminate Gender based Violence and Promote Gender Equality}

When analyzed the Buddha's teachings, it can be found that the root cause behind the violence is polluted mind filled with greed, hatred and delusion. Actually violence starts from mind. A lots of teachings related to elimination of violence and promotion of Gender equality can be found in Tipiakā. Some Teachings of the Buddha are as follows:

\section{Only Biological Difference - The two Bhāva Rupa (Sexes)}

Gender is socially constructed roles and responsibilities assigned to men and women in a given culture and location where as, 'Sex' refers to the biological characteristics of men and women that are universal, obvious, and in general, permanent. Gender roles and responsibilities are determined by the social, cultural and economic environment of the society, and by the prevailing religious, moral, and legal norms. ${ }^{7}$

https://eige.europa.eu/gender-based-violence

4 Gender-Based Violence Initiative Manual. African: Women's Development and Communication Network (FOMENT)/United Nations Fund for Women (UNIFORM), 2003. pp. 63-66

5 Sam Bikash Abhyan Nepal /Canada-Nepal Gender in Organizations (CNGO/Canadian International Development Agency). Violence against Women and Safety STrans.ategies. Kathmandu: SBA Nepal/ CNGO, 2003.

6 Op.cit. (f.n.4), p. 63

7 Kamla, Bhasin. What is Gender? Kathmandu: Shree Shakti (S2), 2001. p.3. 
According to Buddha the difference between men and women are only in biologically but the strength in terms of physically and mentally, they are similar. They possess same capacity of knowledge, skill and other qualities that possess by men. Buddha said the difference lies only in the Bhāva Rupa (sexes). In this light, it is not justifiable to discriminate them from the point of the capacity of knowledge.

\section{The Power of Woman and Five Precepts}

Generally, women are said to be powerful if they have the power of beauty, the power of wealth, the power of relatives and the power of son. In fact, these are the 'power' from the perspectives of social values and norms. But the teachings of Buddha emphases on the virtues to be developed by the women to live happily in this present life and secured for next life. ${ }^{8}$

Five precepts or Pancha Sila or five precepts are also considered as the minimum code of conduct for the lay people from Buddhist perspective. Five precepts are abstaining from the destruction of life, abstaining from taking what is not given, abstains from sexual misconduct, abstains from false speech and abstaining from wine, liquor, and intoxicants that cause negligence. These precepts are the moral conducts or discipline to keep bodily actions and verbal actions properly.

In Dhammapada, Buddha has also stated: ${ }^{9}$ Who so in the world destroys life, tells lies, takes what is not given, resorts to other men's wives and is addicted to intoxicating drinks, such a man digs up his own root in this world. These verses articulate the fact that when one does not follow the five precepts, then one is hampering one's own progress not by others. These five precepts are regarded as a minimum code of conduct for lay disciples. Similarly, in Mahaparinibbāna Sutta, the Buddha also says that a person who always observes the five precepts is certain to get five good results: Great wealth, Good reputation, Self- confidence, untroubled death and a happy state after death. ${ }^{10}$

8 Bhikkhu Bodhi (Trans..), Samyutta Nikāya (The Connected Discourses of the Buddha). Vol. II. Boston: Wisdom Publications. 2000. p.1290.

9 Dhammapada 246. Narada Thera. The Dhammapada. Taipei: The Corporate Body of the Buddhist Educational Foundation, 1993. p. 123.

10 Dunda Bahadur, Bajracharya (Trans.). Digha Nikāya. Lalitpur: Bir-Purna Pustak Sangrahalaya. 2000. p. 106. 
All beings have a right to live and that right should be respected. The practice of Sila helps to develop attitude of respectful. If one wishes to retain feeling of respect, love and compassion should refrain from harming to others as much possible. Only with a kind heart can treat equal behavior to others. Thus, morality helps one to promote good conduct to be free from blameworthy action. Blame worthy action or immoral action produce evil results. Disrespect and violence can be resolved by controlling the persons' misbehavior through practicing five precepts.

\section{Responsibility Sharing between Husband and Wife}

The essentials of happy family life include family members with common aims, good attitudes, and ideals who love, respect and trust each other. In this context Buddha in Sigalovada Sutta, ${ }^{11}$ gave the discourse to Sigala about the actual meaning of veneration in six directions. According to Buddha, the actual meaning of venerating six directions is to fulfill the duties toward six communities including family and the society. Out of six directions, veneration to west is fulfilling the duties toward wife and children.

Patibratā Dharma is commonly practiced in male dominated society. The term patibratā means to win the faith of husband by wife. There is only provision to practice patibrata by wife and not considered about the need to win faith of wife by husband. But, Buddha delivered the discourse about the need of patnibrata also that is to win the faith of wife by husband. As the wives fulfills the duties toward husbands so as the husband also need to fulfill duties toward wife. In general, domestic violence occurs due to conflict between husband and wife in terms of misunderstanding, distrust, irresponsible etc. In Sigalovada Sutta of Digha Nikāya, the Buddha gave a discourse to Sigala. ${ }^{12}$ As such, a husband should serve his wife by honoring her in accordance with her status, not disparaging her, not committing adultery, giving her control of household concerns and giving her occasional gifts of ornaments and clothing. Similarly, a wife should serve her husband by fulfilling the duties. The lack of above mutual responsibility sharing between the husband and the wife is one of the key causes of domestic violence.

\section{Right Speech as a Nonviolent Communication}

Women have to face a verbal violence due to wrong speech. Right speech is one of the paths of Noble Eightfold path taught by the Buddha. Right speech is abstaining from wrong speeches: Musāvada (telling lies), Pisunavāca (slandering), Pharusavāca (harsh speech),

11 Bhikkhu, Amritananda. Buddhakalin Grahasthiharu (Nepali Encyclopedia of Buddha's Time: The Lay people of the Buddha's Time), vol 6. Lalitpur: Bir- Purna Pustak Sangrahalaya. 2018. p. 389.

12 Op.cit. (f.n.11). pp.396-399. 
Samphalapavāca (useless talk). These wrong speeches motivate for verbal violent or violent communication. Thus the Buddha encouraged the disciples to practice right speech: truth speaking, using polite words, Subhāsitvāca (praise words) and Dhhamavāca (meaningful talk). ${ }^{13}$

In relation to the importance of right speech, it has been stated in Dhammapada ${ }^{14}$ : Better than a thousand utterances, comprising useless words, is one single beneficial word, by hearing which one is pacified. Today, right speech is taken widely in the development field as a nonviolent communication.

\section{Saraniya Dhammas and Protection of Domestic Violence}

In Saraniya Sutta of Anguttara Nikāya, Buddha gave a discourse to Bhikkhus about six factors responsible for happiness, friendliness, respecting each other, collectiveness, freedom from disputes and unity. ${ }^{15}$ Saraniya Dhammas include the teachings about establishing bodily actions, verbal actions and mental thoughts of loving kindness towards the co-associates in the holy life openly and secretly, sharing the things whatever rightfully obtained, abide openly and secretly in the virtues and abide openly and secretly in the noble view which leads to the rightful ending of suffering. ${ }^{16}$ To maintain zero tolerance or gender friendly environment within the family the actions of the members done through body, speech and mind should be full of loving kindness. Hatred and violence are the opposite of loving kindness, when loving kindness increases in the family the hatred and violence also decreases and there is harmony and unity in the family.

\section{Promotion of Nonviolence by Practicing Mettā (Loving kindness)}

According to Pāli-English Dictionary of Pāli Text Society, the meaning of the Mettā is loving kindness. The reverse meaning of Mettā is angry, annoyed, irritated etc. which may be the cause for violence. Its natural function is to promote friendliness. The practice of Metta will reduce ill-will. Its proximate cause is seeing loveliness in beings. ${ }^{17}$

13 Klang and Coast Buddhist Association. In Trans. oduction Course in Buddhism. $3^{\text {rd }}$ ed. Maleysia: Klang and Coast Buddhist Association. 2001. p.27.

14 Dhammapada 52. Narad, Op.cit. (f.n.9), p. 55

15 Bhikkhu Bodhi (Trans..). Anguttara Nikāya (The Numerical Discourses of the Buddha). Boston: Wisdom Publications. 2012. p. 866.

16 U Htin, Fatt (Trans..). Saraniya Dhamma \& Mahapaccavekkhana. Rangoon: Buddhist Sassana Nuggaha Organization. 1990. p. 65

17 Bhikkhu, Nanamoli (Trans.). The Path of Purification. Taipei: The Corporate Body of the Buddha Education Foundation. 2001. p. 344. 
Actually anger starts from the mind. It is a destructive emotion that causes much misery in the world and in our own lives. In Visuddhi Magga (Path of purification) ${ }^{18}$, it is stated "By being angry with another, you may or may not make him suffer, but you are certainly suffering now." And "By getting angry you are like a person who wants to hit another and picks up burning ember and had so first burned yourself or made yourself stink. In this way we may or may not harm the other by our anger but we are certainly harming our self."

The meditation practice technique of Mettā is well mentioned in Visuddhi Magga. LovingKindness refers to love without attachment, craving or lust. It is wholesome and genuine desire for the well-being of all being including ourselves. When a person cultivates Metta inside, his or her mental, verbal and physical behavior will be friendliness. Thus, it reduces negative emotion like angry, annoyed, irritated etc. The negative emotions are the destructive emotion that badly affect to the human life and the world. Therefore, Metta practice could be one of the tools to reduce gender based violence and promote gender friendly behavior.

\section{Right Understanding to Eliminate Superstitions Beliefs}

Right Understanding or right vision is the understanding of things as they are. This understanding is the highest wisdom which sees the ultimate reality. Spiritually, it is understanding ultimately of the Four Noble Truths: suffering, cause of suffering, cessations of suffering and path leading to cessation of suffering. But in general sense, it is to keep oneself away from the blind faith or superstitions beliefs. Therefore, the Right understanding is the crucial part for human development.

Thus, lack of right understanding, people are unable to accept the things as it is. Absence of awareness (lack of understanding on what is the problem? what are the cause of the problem, what are the remedy? and what is the best way to solve the problem?) is one of the major causes why women are facing lots of problem. For example, Chhaupadi ${ }^{19}$ is one such superstitions of Nepali tradition that has tortured women from centuries. Women and young girls are kept in isolation during this period. The communities including women take this practice as a part of religion. They because of a wrong view think that if they do not follow such tradition, it will badly affect them and their families. Thus, the values are carrying from generation to generation through socialization process though they may have to encounter with lots of problems such as suffocation due

18 Ibid, p. 345

19 Chhaupadi is the practice of excluding mensTrans.uating women. This is widely practiced particularly in far western Nepal. Women and young girls are confined to a cattle-home or hut (chhaupadi). 
to lack of ventilation, diarrhea due to lack of sanitation, snakes bite and rape during the stay in chhaupadi. Now, Government of Nepal declares that such acts shall be punishable by law. Now a day, it has been controlled to some extent, but still not has been completely stopped. Many chhaugothas (huts) have been destroyed but, they cannot remove the practice from the inner heart. Internalizing the right view could be one of the solutions towards the abolition of Chhaupadi in Nepal. This is just an example but, there are many cases how people fall into the vicious cycle of ignorance owing the lack of right view.

Four noble truth and Eightfold Noble path are Buddha's core teachings which are analyzed as the spiritual subject matter but it could be important teachings and could be applied for reduction of violence and promotion of Gender equality.

Economic Empowerment and Buddhist Teaching Economic empowerment of women is important to make prosperity and raise the status of women. Buddha has also delivered several teachings relating to income earning which helps them for economic empowerment. In Sigalovada Sutta, Buddha delivered the teachings to Singala about the duties of parents to their children: Give education and skill training to their son and daughter is one of the major duties of their parents..$^{20}$ Buddha had inspired the lay persons to put effort in earning at their young age. Different events show that most of the women have skills like spinning yarn from raw cotton, coloring, knitting, tailoring etc. at the time of Buddha.

Buddha had delivered six causes for prosperity such as: A person having good mental and physical health, good virtues, able to accept the ideas of wise person, vast learning, good physical, verbal and mental behavior and attentive and hardworking. Similarly, In Dighajānu Sutta of Ariguttara Nikāya ${ }^{21}$, Buddha had also stated four qualities to raise the living standard: diligences or hard working is necessary to earn money for raising the living standard, assets earned in a righteous way should be preserved properly, a company of good friend could lead them a prosperous life and need of expending according to the income.

\section{Leadership}

Most of the women are far lagging behind in leadership position. This is one of the causes why the overall status of women is low in various field. Hence, the modern Gender approach emphases on the transformation of gender roles of women from followers to decision making roles. Therefore, leadership capacity should be developed. In the Jataka Päli, it

20 Op.cit. (f.n.11), p. 390

21 Bhikkhu Bodhi. Op.cit (f.n.15), pp.1194-1195. 
has mentioned the Dasaraj Dhamma (ten qualities) ${ }^{22}$ : Dana or Generosity, Sila (Virtue), Paricaga (Sacrifice), Ajjava (Working honestly), Madava (Softness), Tapa (Austerity), Akkodha (Following to reason not anger), Avihimsa (Non-violence), Khanti (Patience) and Avirodhana (Non-conflict). These qualities should be followed by womenn who wants to develop leadership qualities.

\section{Conclusion}

Out of 17 Sustainable Development Goals, Gender equality is the fifth goal of SDGs that focus on the achievement of Gender equality and empower all women and girl. Generally, it is said that the root cause of inequality and violence is the unequal power relations between females and males. But, Buddhism not only explains the external factors but also more on inner aspects. The root cause behind inequality and violence is polluted mind filled with greed, hatred and delusion. The polluted or corrupted mind generates destructive emotion and perform violent actions that caused much misery in the world and in our own lives. The Buddha's teachings support to change the person's attitude and develop positive mind. The teachings of the Buddha are close linked with the spirit of Gender equality goal of SDGs. The teachings such as moral conducts (Sila), Right speech, Right livelihood, Right understanding, Saraniya Dhammas, practicing of loving kindness (Mettā) etc are some of the Buddha's teachings presented here that can contribute to non-violence, equality and peace. Such spiritual parts are needs to be incorporated in order to achieve gender equality goal of Sustainable Development Goals.

\section{Work Cited}

Amritananda, Bhikkhu. Buddhakalin Grahasthiharu (Nepali Encyclopedia of Buddha's Time: The Lay people of the Buddha's Time), vol 6. Lalitpur: Bir-Purna Pustak Sangrahalaya, 2018.

Bajracharya, Dunda Bahadur (Trans.). DighaNikāya. Lalitur: Bir-Purna Pustak Sangrahalaya. 2000.

Bhasin, Kamla. What is Gender? Kathmandu: Shree Shakti (S2). 2001.

Bodhi, Bhikkhu (Trans.). Ariguttara Nikāya. Boston: Wisdom Publication. 2012.

Bodhi, Bhikkhu (Trans.). Samyutta Nikaya, vol. II. Boston: Wisdom Publication. 2012. European Institute for Gender Equality. 'Gender-based Violence'. Google. 2019. Access on Nov. 5, 2019. https://eige.europa.eu/gender-based-violence

22 Vipassanā Research Institute. Jataka Pāli Granthamala. Igatpuri: Vipassanā Research Institute, 1998. p. 71 
Fatt, U. Htin. (Trans.). Saraniya Dhamma \& Mahapaccavekkhana. Rangoon: Buddhist Sassana Nuggaha Organization. 1990.

Klang and Coast Buddhist Association. Introduction Course in Buddhism, 3rd ed. Maleysia:

Klang and Coast Buddhist Association. 2001.

Ministry of Women, Children and Social Welfare. 'The Convention on the Elimination of all Forms of Discrimination Against Women' (CEDAW). Kathmandu: Ministry of Women, Children and Social Welfare. 2006.

Nanamoli, Bhikkhu (Trans.). The Path of Purification. Taipei: The Corporate Body of the Buddha Education Foundation. 2001.

Narada. The Dhammapada. Taipei: The Corporate Body of the Buddhist Educational Foundation. 1993.

Sam Bikash Abhyan Nepal /Canada-Nepal Gender in Organizations (CNGO/Canadian International Development Agency). Violence against Women and Safety Strategies. Kathmandu: Sam Bikash Abhiyan Nepal/CNGO. 2003.

United nations Country Team in Nepal. Sustainable Development Goals. Kathmandu: United Nations Country Team in Nepal. UNDP, 2016.

Vipassanā Research Institute. Jataka Pāli Granthamala. Igatpuri: Vipassanā Research Institute. 1998. p. 71. 